3. Про судоустрій і статус суддів: Закон України від 02.06.2016 р. № 1402. Відомості Верховної Ради Украӥни. 2016. № 31. Ст. 545.

4. Позиція судової влади та іiі відносини 3 іншими гілками державної влади в умовах сучасної демократії: висновок Консультативної Ради Європейських судів № 18 (2015). URL: http://rsu.gov.ua/ uploads/article/visnovokno182015-2d678240d2.pdf.

5. Процюк, I. В. (2012). Головні компоненти поділу державної влади. Збірник наукових праџь Харківського національного педагогічного університету імені ГС Сковороди. Право, (19), 5-11.

6. Академічний тлумачний словник української мови. URL: http://sum.in.ua/s/vzajemodija.

DOI https://doi.org/10.30525/978-9934-26-045-2-10

\title{
УПРАВЛІНСЬКИЙ ВПЛИВ ДЕРЖАВИ НА РОЗВИТОК АНТИКОРУПЦЙНОЇ ОСВІТИ: ДОСВІД ЛИТВИ ДЛЯ УКРАЇНИ
}

\author{
Пугач В. Г. \\ кандидат політичних наук, доцент, \\ дочент кафедри менеджменту освіти та права \\ Центрального інституту післядипломної освіти \\ ДЗВО «Університет менеджменту освіти» \\ м. Київ, Україна
}

На шляху становлення та розвитку своєї державності Україна стикається з багатьма загрозами, серед яких найбільш серйозною $\epsilon$ корупція. Незважаючи на те, що за останні роки в Україні вдосконалено антикорупційну нормативно-правову базу, створено розгалужену антикорупційну структуру, тим не менш рівень корупції залишається стабільно високим. Це підтверджується, зокрема, Індексом сприйняття корупції-2020 (CPI) згідно 3 яким Україна 333 балами посіла 117 місце серед 180 країн світу. Крім цього, своє занепокоєння 3 приводу поширеності корупції в Україні висловлюють й зарубіжні партнери. Так, у своєму виступі віце-президент Європейської комісії В.Домбровскіс на засіданні Свропарламенту 9 лютого 2021 року наголосив, що «попри прогрес, широко розповсюджена корупція продовжує стримувати процес реформ в Україні» [1]. 
На жаль, змушені констатувати, що нині в Україні виникла ціла система агресивних активнодіючих факторів, які суттєво уповільнюють iii просування в напрямку формування нульової толерантності до корупції. Втім, на наш погляд, одним з визначальних чинників, що має вкрай негативний наслідок для запобігання i протидії корупції в цілому, є несформованість національної системи антикорупційної освіти. Безумовно, було б несправедливо заперечувати вагомий внесок громадських та міжнародних неурядових організацій у сфері антикорупційної освіти, однак їх сукупний ефект не може компенсувати дефіцит державної уваги щодо питань, пов'язаних з розвитком антикорупційної освіти. Тож, проблемна ситуація у даній сфері актуалізує вивчення зарубіжного досвіду.

Звернення до досвіду Литовської Республіки з питань розвитку антикорупційної освіти є не випадковим. По-перше, Литву і Україну пов'язує спільне історичне минуле. По-друге, Литва має значний позитивний досвід реалізації низки антикорупційних проєктів, які мали на меті підвищення рівня антикорупційної обізнаності громадян. Потретє, антикорупційні освітні заходи в цій країні стартували в ситуації, за якої 72 \% литовців вважали, що хабар вирішує проблеми, 61\% готові були давати хабарі, при цьому 77\% литовців вважали корупцію суспільною проблемою, водночас лише незначна частина готова була до труднощів, пов'язаних з відмовою від корупційної практики [2, с.2]. Схожа ситуація спостерігається й в Україні. Так, згідно з результатами дослідження «Корупція в Україні 2020: розуміння сприйняття, поширеність» 69\% українців вважають корупцію найважливішою проблемою; при цьому близько 42\% - висловили готовність використовувати корупцію в якості інструменту [3].

Аналізуючи литовський досвід у сфері розвитку антикорупційної освіти слід наголосити на активній участі держави. Зокрема, згідно 3 приписами ч. 2 ст. 5 Закону Литовської Республіки «Про запобігання корупції» освіта та інформування громадськості кваліфікуються як превентивні антикорупційні заходи [4]. Також звертає на себе увагу і те, що Спеціальна слідча служба Литовської республіки (Lietuvos Respublikos specialiuju tyrimu tarnyba -STT) - головний антикорупційний правоохоронний орган держави в якості одного 3 провідних напрямків своєї діяльності визначає антикорупційну освіту, яка $€$ «невід'ємною складовою підвищення обізнаності громадськості 3 метою сприяння особистій чесності учнів, студентів, молоді, приватного та державного секторів» [5]. В межах антикорупційного освітнього напрямку STT реалізує низку ініціатив, серед них «Прозорість 
Литви у ваших руках - очистіть себе від корупції», спрямована на заохочення громадськості до активної участі у протидії корупції в Литві [6, с.38]. Про вагому роль литовської держави у справі розвитку антикорупційної освіти свідчить і те, що остання є частиною системи національної освіти. Незважаючи на певний спротив та несприйняття запровадження антикорупційної освіти, в Литві все ж знайшли компромісне рішення, обравши стратегію інтеграції антикорупційної освіти до стандартних програм з різних предметів.

Враховуючи вищезазначене можна 3 впевненістю стверджувати, що антикорупційні освітні заходи відіграють важливу роль у запобіганні та протидії корупції. При цьому для підвищення соціального ефекту антикорупційної освіти принципово важливим $є$ визнання останньої як важливої складової внутрішньої державної політики.

\section{Література:}

1. Віцепрезидент Єврокомісіі: Ми розпочинаємо перегляд умов торгівлі 3 Україною. Європейська правда: веб-сайт. URL: https://www.eurointegration.com.ua/articles/2021/02/10/7119638/

2. Gainer M. Shaping values for a new generation: anti-corruption education in Lithuania, 2002-2006. Innovations for Successful Societies : веб-сайт. URL: https://successfulsocieties.princeton.edu/sites/successful societies/files/Lithuania\%20Shaping\%20Values\%20for\%20a\%20New\%20G eneration_ToU_0.pdf

3. Результати опитування підприємців, експертів i населення «Корупція в Україні 2020: розуміння, сприйняття, поширеність». Украӥнський иентр європейської політики : веб-сайт. URL: https://euaci.eu/ ua/what-we-do/resources/doslidzhennya-korrupciya-v-ua-2020

4. Prevention of Corruption : Law of the Republic of Lithuania as of 28 th May 2002. No. IX-904. URL: https://stt.lt/en/legal-information/laws/4975

5. Special Investigation Service of the Republic of Lithuania : веб-сайт. URL: https://stt.lt/data/public/uploads/2019/11/d1_stt_a4_lanstinukas_4_ final.pdf

6. Annual Report 2019 : Special Investigation Service of the Republic of Lithuania : веб-сайт. URL: https://www.stt.lt/en/doclib/ oflnfolbhmfv3h73f1wenwnc22ssqzwk 